Available online at http://jgu.garmian.edu.krd

Journal of University of Garmian

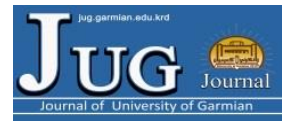

https://doi.org/10.24271/garmian.196359

\title{
In Nature is Joy: An Ecopsychological Study of Alice Walker's Selected Poems
}

\author{
Zanyar Faiq Saied ${ }^{1}$, Firmesk Othman Rahim ${ }^{2}$ \\ 1 Department of English, College of Languages, Komar University of Science and Technology \\ 2 Department of English, College of Education, University of Garmian
}

\section{Article Info}

Received: July, 2019

Revised:August,2019

Accepted: September ,2019

\section{Keywords}

Alice Walker,

Ecocriticism,

Ecopsychology,

Environment, Nature,

Human being

\section{Abstract}

The relationship between literature and nature has been reflected in the literary works of the cultures of the world. In the last decades of the $20^{\text {th }}$ century, literary theory witnessed a paradigm shift about nature writing when writers began to raise the environmental issues in their writings. As a result of many attempts, Ecocriticism appeared as an academic discipline to focus on the 'Earth-centric' approach to nature writing in an age of global environmental crisis. This paper investigates the rise of the environmental literary theory. Likewise, the theory of Ecocriticism, its principles, and aims are explained. Moreover, Ecopsychology, which is the main theory to analyze the poems of Alice Walker, is explained. This paper demonstrates how important renewing of the good relationship between human beings and nature is to make the Earth a joyful place to live on.

\section{Corresponding Author}

\section{Intro duction}

The Earth is facing serious environmental problems nowadays. The problems started from a time when human beings decided to build industrial cities, factories, and advanced technologies. The problems like global warming, pollution, and climate change have affected the life of every being on the planet. They reached an alarming time that influenced writers and environmentalists to raise their voices against all human actions that destruct the environment and the Earth.

The serious attempts of the writers resulted in the rise of literary environmental theory "Ecocriticism" in the last decades of the twentieth century. The theory appeared as a need for changing the contemporary human beings' paradigm 
of nature. Ecocriticism reconsiders the human-nature relation through the literary works as a way for making a positive change in human being's understanding of their surroundings and the Earth.

Today, the theory is widened and merged with other social sciences to make a change in people's life. In this regard, both ecology and psychology are merged in Ecopsychology as a new theory to reconnect human psyche to the natural world. The theory of Ecopsychology focuses on awakening human being's unconscious mind regarding the environment. It requires human beings to experience nature to make a deep relation with the natural elements. However, this paper studies the importance of human beings' relation to nature as a way of making life sustainable and joyful for all species.

The paper studies the poems of Alice Walker who is regarded as one of the vital voices today in defending the Earth. Her positive thinking, healthy behavior, and kindness toward the natural elements are reflected in her poems that make her an influential voice. Therefore, a number of Walker's poems are selected to make the reader familiar with her views on nature and her positive attitude toward every natural entity around. Walker's thinking and behavior in this way are what makes her an optimistic person who can find joy in the hard time.

\section{The Rise of Ecocriticism}

In the last decades of the twentieth century, Ecocriticism emerged as a new literary theory to reconsider the relation of human beings to the natural world. The term 'Ecocriticism' is coined in 1978 for the first time by William
Rueckert. It is composed from both 'ecology' and 'criticism'. The word 'ecology' comes from the Greek word 'Oikos' meaning 'house' or 'home' and criticism comes from 'kritikos' meaning 'able to judge'. William Howarth interpreted the term to mean 'house judge'. Here, Howarth regards 'nature' as the 'home' or a house and 'criticism' to judge the quality and integrity of that home. Based on this, Ecocriticism analyzes the literary expressions of human beings related to natural world (Fenn, 115).

Before starting with Ecocriticism, it is important to mention that the science of 'ecology' studies the interactions among organisms and their environment. It is generally defined as the way in which plants, animals and people are related to one another and their surroundings. Donald Hughes, in this regard, says:

[h] uman ecology . . . is a rational study of how mankind interrelates with the home of the human species, the earth; with its soil and mineral resources; with its water, both fresh and salt; with its air, climates and weather; with its many living things, animals and planets, from the simplest to the most complex; and with the energy received ultimately from the sun (qtd. in Ben G., 13).

Ecology, therefore, is viewed as the natural web of life and human being stands somewhere in the web (Ben G., 15). However, criticism comes to judge this natural web in which human being is regarded as superior and other species inferior. Critics in the last decade of the twentieth century started their attempt to 
define the theory specifically and find what the theory exactly stands for.

William Rueckert, a dominant name in the field, defines Ecocriticism as "the application of ecology and ecological concepts to the study of literature" (Glotfelty and Harold Fromm, xx). Later, in 1996, Cheryll Glotfelty, known as the pioneer of Ecocriticism, defines Ecocriticism as simply "the study of the relationship between literature and the physical environment." Glotfelty continues saying "just as feminist criticism examines language and literature from a gender-conscious perspective and Marxist criticism brings an awareness of modes of production and economic class to its reading of texts, ecocriticism takes an earth-centered approach to literary studies" (qtd. in Glotfelty and Harold Formm, xviii).

Based on the definitions, Ecocriticism addresses issues concerning human being's relation to nature that have previously been marginalized by the literary academy (Hoffman et al, 151). It focuses on simplicity, beauty, equality, esteem, and awareness among the species and with the physical world. Ecocritics do not see beauty in the natural sceneries alone, but beauty is also in the mutual human-nature relationship. The real beauty is having all the species including human beings as one family of the Earth. Likewise, it advocates the preservation of animals and plants that are the indispensible part of the ecosystem because every organism has its value in its existence and play a role in the natural web of life (Mishra, 438).

Today, the theory of Ecocriticism is widened and attached to other social and humanitarian sciences. In many fields, it can be found that the prefix 'eco' attached to different approaches like ecopolitics, eco-feminism, eco-psychology, eco-terrorism, and even eco-phobia. Merging the theory with other social sciences is a need for making a change in the life of the whole species today. In this regard, the prefix 'eco' is attached to psychology to make a new discipline to reconnect human being's psyche to nature. The immediate wide spread of the theory indicates its importance in analyzing the various issues facing the life of species and the whole Earth.

\section{Ecopsychology}

Ecopsychology as a term was first coined by Theodore Roszak in The Voice of the Earth in 1992. It comes from both 'psychology' meaning "study of spirit or soul", and 'eco' meaning 'home'. Therefore, Ecopsychology is a combination of both 'ecology' and 'psychology' which approach human psyche in relation to its earthly or natural home (Fisher, 4). Coining the term was an influential attempt to bring both environmentalists and psychologists together for a discussion for the advantage of the both fields. As a result of their attempt, Ecopsychology became a new academic field with the purpose of studying the inner world of human beings in relation to the outer world (Corbett and Martin Milton, 31).

The theory has been recognized by several names like 'ecotherapy', 'green therapy', 'Earth-centered therapy', and 'nature-based psychotherapy'. In this regard, Whit Hibbard explains that Ecopsychology refers to the 'greening of psychology' by which he means the healing of human psyche in relation to 
nature (28, 2003). Many critics and scholars defined the theory to find its core objectives. Generally, Ecopsychology is defined as an approach that studies the relationship between human beings and the natural world through ecological and psychological principles. It seeks both psychologists and ecologists to develop and understand the ways of expanding the emotional connection between individuals and the natural world (Blaschke, 3). In fact, the relation of human beings to nature is not a new subject in literature. For this reason, scholars like John Davis and Canty define Ecopsychology as a reawakening and development of the lost connection of human beings to nature (10, 2013).

However, the emergence of Ecopsychology in the complexities of the contemporary age is a need to awaken human beings' unconscious mind to the fact that the Earth faces many ecological challenges. It is important to state that revealing the ecological challenges the Earth faces is not for making unnecessary fear, but is that human being is the most impactful user of a great amount of the natural resources without ecological consciousness (Fisher, 5).

It was Theodore Roszak who first introduced the concept of 'ecological unconscious' which is a link between human beings' psyche and the outer world (Davis and Canty, 8). Ecopsychology supports ecological consciousness by awakening human being's! unconscious mind. In this regard, Roszak refers to the human beings' unconsciousness about his surroundings. He says "The core of the mind is the ecological unconscious. For ecopsychology, repression of the ecological unconscious is the deepest root of collusive madness in industrial society. Open access to the ecological unconscious is the path to sanity" (qtd. in Hibbard, 44). Roszak argues that reaching the unconscious mind in an industrial time is not easy, but human being should realize that to get a healthy mind and behavior toward the natural world there should be an awakening of the unconscious mind.

Roszak for the ecological consciousness encourages human beings to experience nature from early childhood as he says "the ecological unconscious is regenerated, as if it were a gift, in the newborn's enchanted sense of the world. Ecopsychology seeks to recover the child's innately animistic quality of experience in functionally "sane" adults" (qtd. in Hibbard, 44). In this regard, Howard Clinebell argues that Ecopsychology helps human beings to recover this gift as a resource for developing what Roszak calls 'the ecological ego' which is important for changing human being's! thinking and behavior toward nature. Roszak believes that positive attitudes and actions towards the natural world can be fostered in childhood to develop a spiritual and emotional relation with nature. It is a way to help individuals to respect the entire ecosystem by putting their spirit among the eco-family.

Today, human civilization is facing a critical turning point regarding the Earth and environment. Beside the man-made factors, the lack of will to change the cultural paradigm toward nature is also problematic. Ecocritics believe that human beings should be awakened that today's behavior and thinking toward nature produce tomorrow's problems (Leigh, 3). For this 
reason, Ecopsychologists argue that the health of human beings is connected to the health of the planet and that both are mutually inclusive of the other (Leigh, 6). Usually, a healthy relationship is naturally mutual and helpful to both parties maintain a positive outlook by keeping away from feelings of depression, anxiety, anger, and overwhelm (Carrington, 7). Therefore, the reconnection of human psyche to nature is important to maintain a healthy life.

In fact, there is no verbal communication between human beings and nature, but a deep communication is needed between the inner and the outer world. Ecopsychology requires moving deep into inner world to make a connection more than an analytical one. Nature, as a phenomenon of the physical world collectively, includes plants, animals, landscape, and other features and products of the Earth. In this regard, the relationship with nature is one in which human beings interact with elements like plants, animals and the landscape (Carrington, 7). Ecopsychology encourages the direct contact with nature to make individual conscious and aware about the surroundings. In addition, the deep human-nature reconnection supports individuals to think positively and change the feelings of anxiety and sadness to joy and love.

\section{Alice Walker: Voice of Nature}

Walker is an American writer and activist who started writing at the age of eight. She was accidentally wounded in the right eye from childhood which made her suffer psychologically from alienation and depression. Her depression made her turn deeply into reading and writing, and experiencing the natural world which became the source of her strong inner vision of art (Byrd, 24).

Walker is one of the truthful voices that show the truth of the life of people and all the creatures. She shows the threats that human and non-human beings are facing today (Plant, xvi, 2017). Her attitude towards nature is that of a worshipper. In an interview with John O'Brien, she says "Certainly I don't believe there is a God beyond nature. The world is God. Man is God. So is a leaf or a snake....So." (qtd. in Byrd, 213). This statement indicates that Walker regards nature as the source of her being. She states that the greatest value a person can attain is full humanity which is a state of oneness with all things (Ibid, 62). She also regards nature as the spirit of the world. In another interview in 1993, a conversation with Jean Shinoda Bolen and Isabel Allende, she answers a question about her God and how does He look like. She answers "My God is the earth and looks like the earth. That's it". She also adds" "The earth is my God, and nature is its spirit" (Ibid, 111).

These statements by Walker clearly indicate her strong faith in nature and its power. It is also making readers see her strong inner relation with nature which makes her respect every element of nature including animals, natural places, and plants, animates and inanimate. Therefore, a number of Walker's poems are selected below to study and to hear her voice defending the Earth; and also her deep relation with the natural elements which makes her an optimistic person. 
A. Walker's Voice against Nature Destruction

Ecopsychology, as mentioned before, focuses on ecological consciousness by awakening human beings' unconscious mind and reconnecting human beings to nature. In this regard, Walker chooses poetry as a method to make human beings conscious about their surroundings and make them to feel both the beauty and importance of the natural world around. Walker is famous for being an Earthling voice that defends the Earth and the species. Her poetry demonstrates her attention toward the destructions happening to natural world by human beings. She attempts to defend every natural element like plants, trees, mountains, oceans, animals, and other beings to awaken the world that all the surroundings have their own values and deserve to be respected.

Walker's poetry shows the fear of all species from human actions that cause destruction on the Earth. She shows the sufferings of human beings, animals, and plants from the modern industrial progress today. In her poem, "We Have a Map of the World", she starts with a statement of Raymond Yowell in 1988, who says "we have a map/ of the world/ showing how/ all nuclear tests/ have been/ conducted/ on the territory/of Native/ peoples" (Walker, 436). In this statement of Raymond, the poet reminds the reader about the destructions the Earth faced in the twentieth century because of using nuclear weapons in some countries which caused millions of deaths, pollutions to lands, destroying animals, and plants. Walker shows the fear and concern of people that are suffering from the destructions happened to the Earth. At the same time, she globalizes the environmental issues to make the reader think about the environmental issues universally not a mere issue of a country or a place. The poet says "as it is/ in my country/ so it is/ in yours" (Walker, 436) by which she refers to the environmental issue in her country as the same issue of other people's countries in Asia and India. She says:

\section{I look into}

your Asian

your Indian

eyes

and read your fear:

that your cows

eat

poisoned

grass:

that your wheat

kills

that your children

shrink

from contact with mother's

milk.

(Walker, 436-37)

Walker expresses the fear of human beings from the destruction caused by human beings themselves. The wars that happened in modern world have had impacts on both urban and rural environment. As a consequence of war, military campaigns and destruction, pollution problems appeared. Oceans and air have been polluted (Closmann and Christof Mauch, 167). Therefore, the poem shows the sufferings of people, animals, and plants from the destructions caused by war to the Earth.

Indeed, it is not only human beings that fear from the destructions happening to the natural world. In her 
poem "The Tree", she shows the fear of a tree from human being's action. In the poem, the shaman José reveals that his community no longer dream of the 'World Tree' that "reached from / Heaven to earth / Earth to heaven," (Walker, 107) and sang. The cutting down of the rainforests, a consequence of modern man's dominion of the Earth, has scattered his people who are sick and dying (Walker, 107).

But now
he said
our people are
dying
many are sick
many are scattered
the rainforest
is being
cut down.
The tree does
not come
to us
it does not
sing
to us
anymore.

Usually a rainforest can be described as a tall and dense jungle which gets a high amount of rainfall per year. The poet talks about the singing of the trees which is no more heard by people. Here, singing might refer to the sounds one can hear in the rainforest which is a mixture of birds, water, and insects that makes the place unique. The poet states that these sounds cannot be heard now as a result of cutting down the forests which makes the animals and other beings sick, homeless and displaced. In another stanza, she says:

Now I understand

\& said this
To

José: Though it is the world tree

\& larger than the world

It was afraid to sing aloud.

It was looking

For shelter

Even in

My

Small space.

Walker refers to the fear of the 'world tree' that was 'larger than the world' was afraid to sing aloud, and was seeking shelter in the dream of one dreamer. Walker's image of the tree seeking a shelter is an influential line that determine a great deal in the world has gone wrong. A tree, whose body which is usually used for human shelter seeks shelter in the body of a human now (Plant, 167). Although, the tree is describes as powerful as strong in a way 'presented itself' to the poet, but the destructions caused the tree to fear of singing aloud.

Despite its sufferings, walker shows that the tree comes to human beings to ask for a shelter which might imply the tree's identity with humankind and its faith in humanity to change their behavior and save it. This message is walker's serious message sent to humanity to be conscious and take the responsibility of protecting the planet Earth (Ibid, 167). Walker through her writing shows the disrespectful behavior of human beings toward other beings. In one essay entitled "Everything is a Human Being", she narrates her speech with 'trees'. She talks to the trees and says "I love trees" (Walker, 73). But the trees reply "Human, please" (Walker, 73). The answer of the trees indicates a surprise that trees do not believe in human being's 
love to them. Walker continues and says "But I do not cut you down in the prime of life. I do not haul your mutilated and stripped bodies shamelessly down the highway. It is the lumber companies" (Ibid, 73), but the tree reply "Just go away" (Ibid, 73). Walker replies "All my life you have meant a lot to me. I love your grace, your dignity, your serenity, your generosity..." (Ibid, 73), but the tree interrupts her saying:

Well, we find you without grace, without dignity, without serenity, and there is no generosity in you either-just ask any tree. You butcher us, you burn us, you grow us only to destroy us. Even when we grow ourselves, you kill us, or cut off our limbs. That we are alive and have feelings means nothing to you. (Walker, 73)

Although Walker regards herself as an individual and innocent, but she admits that for the trees being an individual does not matter. She says "Just as human beings perceive all trees as one, all human beings, to the trees, are one" (Walker, 73). Walker says" we are judged by our worst collective behavior...The Earth holds us responsible for our crimes against it, not as individuals, but as a species - this was the message of the trees" (Ibid, 73).

In showing the fear and sufferings of animal class, Walker says "we are connected to animals at least as intimately as we are connected to trees" (qtd. in Delveaux, 10). In her poem "In Everything I Do" she talks about the suffering of animals like 'monkey'. The poet talks about monkey in two stages of her life. In the childhood the poet's friendship with the monkey gives her a feeling of joy and happiness, but when she grows up she finds how the monkey is tortured by human beings.

Then I grew up
To learn
how very
Clever
Intelligent
Wise
Funny
\& sweetly
Beautiful
The monkey
Is
\& how
It is tortured.

The poet uses the words 'clever', intelligent', wise' which she has found after she experienced the life of the monkey. She also uses the word 'funny' which indicates that in the relation of the poet to the monkey she has felt fun and pleasure. However, the poet gives two messages to the reader that the humananimal relation makes human life enjoyable with fun and pleasure. The second point is that in such relationships human can discover and understand the sufferings of other beings, which are mostly tortured by human beings.

Walker's writing also shows the sufferings of other animals like cows, deer, snakes, elephants, and horses. In an essay entitled "Am I Blue" she talks about horses and how they are treated as slaves by human beings. Walker states that the sufferings of animals have pushed her to become a non-meat-eating person (Walker, 94).

Walker has always criticized the human beings for their actions toward the 
species and the natural elements including herself as she says:

How can Humanity
Look the deer
in
The face?
How can I,
Having erected
my fence?

Walker does not stop only at showing the facts that human beings, animals, and plants have faced, but she calls to terminate these destructions. She believes that the Earth destructors are haters of the Earth and they are "The old pale heart vampires/sucking up the world" (Walker, 440). Walker wants her readers to be aware of the actions of the Earth destructors. In a statement she says "they could shoot me to another planet, but because I'm made of earth, I could never leave. That is my home, that is what I am. I love this feeling of always being at home and always being with what is sacred to me, what is divine to me" (Ferris, 7).

Walker calls people, the Earthlings, to gather and put an end to the human actions that spoil the natural world. Walker calls "O poets/ singers/ and children/ of the world/ unite/ Lift every/ voice/ and sing/ out/ against the old men/ who hate us/ hate themselves/ and hate/ The earth" (Walker, 439-40). She demands the different categories of people to raise their voices against those who destroy the natural world and lead the Earth to an unknown destiny because she believes that "the world rising/can put an end/to anything/the murder of children /whales/elephants/forests/oceans" (Walker, 47).
Walker uses the word 'murder' to refer to the collapsing of natural elements. This statement indicates the intentional destroying of nature by human beings. Therefore, Walker seeks to start changing toward nature by putting the spirit in nature because "you cannot separate yourself ever from the earth. . . . If you understand that, you lose all fear of dying. You may be grass, you may be a cow, but you'll always be here, in fact even if they shoot you" (Ferris, 5).

Through her poems, she seeks a change in human being's psyche toward consciousness about their surroundings. In a poem she says "get up. Roll over/ on that part/ of you/ that will not/ welcome/ recognize/ encourage/ or even see/ our rise" (Walker, 47). Walker encourages human beings or her readers to awaken their unconscious mind toward nature. She asks those people who are unaware about the ecosystem collapsing. She demands those people to support the environmentalists who are defending the Earth.

In another poem, with an angry voice and in an imperative way she seeks people to "stop/nodding off/about this" (Walker, 119). She demands to wake up in a way not to get asleep again to protect the 'Mother Earth' and the 'Father Sky'. Walker states that if human beings become aware to protect the Earth and the Sky then the life of whole will be changed and sustainable under protection.

let us resolve not

to fall asleep again

or forget

that to protect

Mother Earth

(and Father Sky 
who is also under

attack)

is to protect

us all

who are

from here. (walker, 123)

\section{B. The Joy of Human-Nature Relation}

It is undeniable that nature is part of human beings' life, and human beings develop among the natural elements belonging to the Earth. Therefore, both humans and nature are part of one ecosystem, but there is always a rapid change in human being's! minds to regard themselves as animals as others or as one part of the system. Ecopsychology comes to remind human beings about their surroundings to make them have a sense of communion with the natural world.

The relation can be developed from the childhood when the spirit of a child, their eyes and ears, and their sense of smell grow within the natural surroundings. Walker's childhood experiences have influenced her in adulthood behavior toward nature. In her poem "The Place Where I Was Born", Walker shows the reader how she has developed her positive attitudes toward the natural world from the childhood relation to it. The poem is a long one with the refrain ' $\mathrm{O}$, landscape of my birth' in all the stanzas. This refrain makes the place more memorable to the reader on how deep relation of the poet and the natural setting has influenced her during a life.

\section{$O$, landscape of my birth}

because you were so good to me as I grew
I could not bear to lose you. $O$, landscape of my birth because when I lost you, a part of my soul died.

$O$, landscape of my birth

because to save myself I pretended it was you

Who died. (walker, 413-14)

The tone of the poet sounds sorrowful and nostalgic when she remembers the goodness of her landscape to her and her separation from it. Walker talks about the goodness of the landscape during her growth process. She states that the kindness of the landscape has made her unable to accept the reality of their detachment and could hardly endure the fact. As the approach of Ecopsychology argues, the separation of human beings from the natural world makes an individual suffer deeply. This can reflect in the first stanza when Walker repeats that her separation with the landscape has made her suffer in away part of her soul has 'died'.

The word 'died' is repeated two times in the stanza, one time for the poet and the second time for the landscape. This expression gives a significant role to the existing of the landscape in the poet's life. Despite this, the landscape is personified as someone that can live and die. Here, the relation between the poet and the natural world can be noticed as two member of a family, two friends, or two persons that separation has made them died.

Ecopsychologists believe that a healthy human-nature relationship is important to make life sustainable for all. In this regard, Walker is a person who always returns to nature to make her spirit 
relax and happy. Her poetry demonstrates her strong spiritual and emotional relation with nature which developed from her childhood. In a statement, she talks about her moving from place to place to find a comfortable natural setting. Regarding her move from Brooklyn to northern California in1978, she says "it was one of the best decisions I ever made. My spirit, which had felt so cramped on the East Coast, expanded fully, and I found as my presences to explore within my psyche as I was beginning to recognize in the world (Walker, 311). She states that her looking to find more natural places to live in was the best decisions in her life by which she could regain her spirit with nature.

The childhood spiritual relation with nature has always remained in Walker. In an interview with Rudolph P. Byrd on raising chickens she states that seeing the hen and her chicks in Bali on a dirt road made her realize that "they were grace-launched messengers with ties to the unconscious sent to awaken me to the possibility of regaining some of what I had lost: my memory of many, many years of my childhood that I had completely forgotten" (Byrd, 2009). These statements can demonstrate her desire to always return to nature as she feels something is lost in her life. This desire can also be seen in her poems when she says:

You that now did not exist

because I could not see you.

But $O$, landscape of my birth

now I can confess how I have lied. (walker, 414)

Walker grievously admits that she has lied with herself when she has regarded her childhood landscape as 'died'. The truth is that the landscape and her memories have never died in her heart and mind. The physical separation of the two has not affected the deep relation between them. Walker says "Soon I will have known fifty summers/ Perhaps that is why/ my heart/ an imprisoned tree/ so long clutched tight/ inside its core/ insists/ on shedding/ like iron leaves/ the bars/ from its cell." Walker talks about how long she has been separated from her landscape setting. After 'fifty summers' the poet's heart is still a captive. The poet refers to 'summer' in the poem which is a warm season. The warmth of the season might be a symbol for love, affection, and good relationship between the poet and the natural elements. This expression might also refer to that part of the year in which people can spend more time in nature, walking, seeing flowers, the trees, the grass, the birds and other little creatures. Despite the physical separation of the poet, to her childhood landscape, the deep relation after fifty summers is still commemorating with the natural world.

The deep relation of the poet to the natural world comes from her conscious mind about the surrounding which always makes her feel that something is lost in her life. She reactivates her spiritual feeling which is retrieved in her from childhood. The inner strong relation of the poet with the natural world can be noticed more when she says "You flow into me" like the "Aborigine or Bushperson or Cherokee/ who braves everything/ to stumble home to die/ no matter that cowboys/ are herding/ cattle where the ancestors slept/ I return to you, my earliest love." Walker speaks of her 
return to nature despite all the difficulties she faces. Her lines demonstrate her as strong as those brave people who face every difficulty to return home. She refers to 'Aborigine', 'Bushperson' and 'Cherokee' who are all indigenous peoples of Australia, Southern Africa, and Southeastern Woodlands of the United States. These native people live as the primitive peoples in islands, forests, and their way of living is more natural not like the artificial living of the cities. They are closely linked to the place in which they live, and they do not move away aimlessly from their original place. Here, walker states that she does the same thing as these natives to return to her 'earliest love', the landscape.

Walker's return to nature is without any surprise when she says "O landscape of my Birth/ you have never been far from my heart/ it is I who have been far/ If you will take me back/ Know that I/ Am yours." These lines indicate that returning of the poet to her natural world is not a surprising because after fifty summers she has realized that happiness, relaxation and joy can be found in reconnecting her inner world with the natural world.

Walker expresses nature's closeness to human beings. She sates that it is not nature that leaves human beings, nature remains in humans, but it is human beings who! leave the natural world. The poet asks for the reconnection between the landscape and her as she says 'Am yours', i.e., that the spirit of the poet needs to reconnect with the natural world to recover from her sadness and enjoy the joy again she has experienced in her childhood.
Walker's strong spirit in challenging the life difficulties comes from her connectedness to nature. She believes that the spiritual relation with nature makes an individual be different with others. Walker states that because of her works that are rooted in spirituality rather than in politics, she is able to follow the sense of being one with other people and other beings much more easily (Ferris, 9). In her poem "On Stripping Bark from Myself”, she says:

My struggle was always against

an inner darkness: I carry within myself the only known keys to my death---to unlock life, or close it shut forever. A woman who loves wood grains, the color yellow. And the sun, I am happy to fight all outside murderers

as $I$ see I must.

(Walker, 271)

Fighting against inner darkness in an age which seems impossible for one to escape from is challenging. The world events, TV reports, researches, and recent trends all seem to highlight the brutality of humanity. In the mid of this brutality, Walker is a fresh reminder that human beings have the capacity to love, make peace, and share equality (Stapleton, 309). Walker in this poem refers to the psyche of human beings "inner darkness". She uses the word "bark" metaphorically a in the poem's title. She compares herself to trees. The metaphor might indicate two points. Firstly, usually trees have barks that cover the outside of the tree and it is made up of several layers. Here, Walker states that she strips the bark of herself which indicate that she uncover her 
psyche and moves deep into the inner world to question the essence of her own feelings and sentiments about the world. Secondly, removing the barks might show that Walker releases her soul or spirit from the prison of the body so as to unite with nature. In her tone, she seems confident because she is a woman who loves nature 'wood grains', 'color yellow', 'the sun'. She fights all the 'outside murderers' which might refer to all those who destroy the ecosystem by their actions, all those who ruin people's happiness and health. Walker uses the modal verb 'must' which indicates she is obliged to fight against the 'inner darkness' and 'outside murderers'.

Walker calls her readers to be in communion with nature, not in words only, but be a real part of nature. She attempts to make human beings aware that everyone belongs to all that is around. Therefore, they should be able to love all that as a way to change the life on the Earth. In the introduction to her volume The World Will Follow Joy, she says:

We will turn our madness into flowers as a way of moving completely beyond all previous and current programming of how we must toe the familiar line of submission and fear, following orders given us by miserable souls who, somehow, have managed to almost completely control us. We will discover something wonderful: that the world really does not enjoy following the dictates of sociopaths and psychopaths, those who treat the earth, our mother, as if she is wrong, and must be constantly corrected, in as sadistic and domineering a way as that of a drunken husband who kills his wife.

(Walker, xiv)

Walker supports returning to nature and the Earth as a way of facing the difficulties in every aspects of life either socially, politically, or culturally. In this poem "Turning Madness into Flowers", her positive thinking is expressed. Her word comfort one's feeling at the time of grief and disappointment. The poem is a reminder of the capacity to come together and take action in the most troubled times (Stapleton, 309). She encourages human beings to touch the sorrows and strongly take the grief because "our grief bringing/ us home” (Walker, 20).

Speaking for you, hanging, weeping, over the

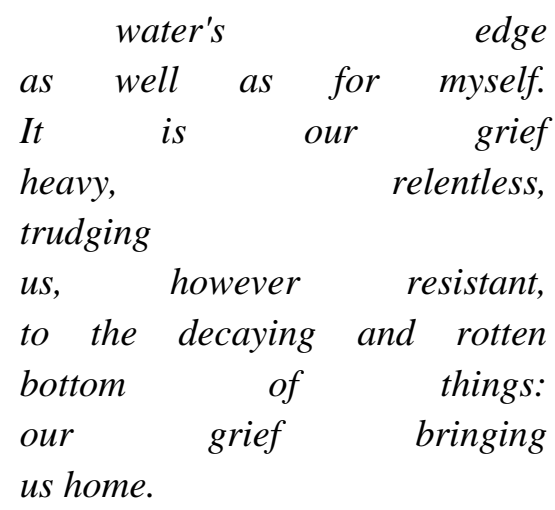

Walker's joy comes from the belief that a sustainable life is based on protecting others not destroying them. Joy comes from equality and justice with other species that exist already, or that might come into existence. Walker's message is that human beings belong to the Earth and separation from the Earth perhaps leads to the greatest damage and loss. 


\section{Conclusion}

The threat on the future of the Earth is serious and unpleasant. Therefore, an influential place to make it possible to hear the song of the Earth is literature through which the gaps between human relations to natural world can be found. Alice Walker's poetry of nature and her personification of non-human beings; the life sharing with animals; the

1. Byrd, Rudolph P. The World Has Changed: Conversation With Alice Walker. The New press, New York, United States

2. Corbett, Lisa, and Martin Milton. Ecopsychology: A perspective on trauma. European Journal of Ecopsychology, University of Surrey, UK (2011), pp. 31

3. Fenn, Vathana. Roots of Ecocriticism: An Exploration of the History of Ecocriticism, a Literary Theory of the Post-Modern World. Journal of English Language and Literature (JOELL), vol. 2, no. 2, 2015, pp.115, http://www.joell.in

4. Fisher, Andy. Radical Ecopsychology: Psychology in the Service of Life. Edited by Roger S. Gottlieb, $2^{\text {nd }}$ ed., State University of New York Press, Albany, United States of America, 2013, pp. 4, 5

5. Glotfelty, Cheryll, and Harold Fromm. The Ecocriticism Reader: Landmarks in Literary Ecology. The University of Georgia Press, Athens, Georgia 1996, pp. xix, $\mathrm{xx}, \mathrm{xviii}$

6. Hibbard, Whit. Ecopsychology: A Review. The Trumpeter Volume 19, Number 2 (2003) pp. 44 published on http://trumpeter.athabascau.ca/index.php /trumpet/article/viewFile/93/96 speaking of trees; her love to all animate and inanimate beings demonstrate her as an important ecological voice today. Her poems reveal a fact that both human beings and natural world need a sense of communion to give life sustainability and joy.

\section{Works Cited}

7. Hoffman, Elizabeth, and Malcolm A. Nelson, general editors. Ecocriticism: Creating Self and Place in Environmental and American Indian Literatures. Peter Lang Publishing, vol. 15, New York, United States, 2013, pp. 151

8. Mishra, Sandip Kumar. Ecocriticism as a Reappraisal of Romanticism Ecocriticism as a Reappraisal of Romanticism. KIIT University, Vol. II, Issue III, August 2017, published on https://www.researchgate.net/publicatio n/319415801, pp. 438

9. Plant, Deborah G. Alice Walker: A Woman for Our Times. Ed. Joanne M. Braxton, California, 2017, pp. 167

10. Walker, Alice. The Blue Body Everything We Know. The women's press, Britain, 1991, pp. 436-441, 459, 413-415

11. ---. Horses Make a Landscape Look More Beautiful. The Women's Press, London, 1984, pp. 44, 54, 59, 63

12. ---. Taking the Arrow Out of the Heart. ATRIA, 37 Inc., New York, 2018, pp. 47,119

13. ---. The World Will Follow Joy: Turning Madness into Flowers. The New Press, New York, 2013, pp. xiv, 15, 18, 19, 29 
14. ---. Living by the Word, (Essays). Open Road, Integrated Media, New York, 1988, pp. 73

15. Ferris, William R. Alice Walker: I know what the earth says. The University of North Carolina Press, vol. 10, no. 1, 2004, pp. 7-9

16. Stapleton, Evan. Review of The World Will Follow Joy: Turning Madness into Flowers, by Alice Walker. Rocky Mountain Review of Language and Literature, vol. 69 no. 2, 2015, p. 309310.

Project

MUSE muse.jhu.edu/article/603943.

17. Delveaux, Martin. Transcending Ecofeminism: Alice Walker, Spiritual Ecowomanism, and Environmental EthicsUniversity of Exeter, UK, 2001, pp. 10

18. Closmann, Charles, and Christof Mauch (Conveners). War and the Environment: Contexts and Consequences of Military Destruction in the Modern Age. Conference at the GHI, May 7-8, 2004, pp. 167

19. Davis, John V, and Jeanine M. Canty. Ecopsychology and Transpersonal
Psychology, In Friedman, H. L., \& Hartelius, G. (Eds.), 2013, pp. 597 611.

20. Blaschke, Paul. Health and Wellbeing Benefits Of Conservation In New Zealand, New Zealand Department of Conservation, 2013, pp.3, 10

21. Carrington, Kayla. Activist Poetics: Intersecting Ecopsychology and Poetry to Inspire Environmental Action. University of Washington, Seattle, 2018, pp.7

22. JolsnaBen, G. Ecology as Literature: A Reading of Gerald Durrell. Mahatan Ghandhi University, MG University Research Center, 2002, p. 12 published on

https://shodhganga.inflibnet.ac.in/handle /10603/522

23. Leigh, Peter. The Ecological Crisis, The Human Condition, And CommunityBased Restoration as An Instrument for Its Cure. Ethics in Science and Environmental Politics ESEP, USA, 2005, pp. 3, 6 